\title{
Kulturális különbözőségek elfogadása a külföldi orvostanhallgatók beilleszkedésében
}

\author{
Faubl Nóra dr. ${ }^{1}$ - Pótó Zsuzsanna dr. ${ }^{1}$ - Marek Erika dr. ${ }^{2}$ \\ Birkás Béla dr. ${ }^{1}$ - Füzesi Zsuzsanna dr. ${ }^{1}$ - Németh Timea dr. ${ }^{3}$ \\ ${ }^{1}$ Pécsi Tudományegyetem, Általános Orvostudományi Kar, Magatartástudományi Intézet, Pécs \\ ${ }^{2}$ Pécsi Tudományegyetem, Általános Orvostudományi Kar, Múveleti Medicina Tanszék, Pécs \\ ${ }^{3}$ Pécsi Tudományegyetem, Általános Orvostudományi Kar, Egészségügyi Nyelvi és Kommunikációs Intézet, Pécs
}

Bevezetés: A 21. századra a multikulturális társadalmi közegben az interkulturális tudás, mint készség, fokozott mértékben válik kulcskompetenciává. E társadalmi kompetencia elsajátításának egyik lehetséges területe a nemzetközi hallgatói mobilitás, mely világszerte, így hazánkban is, egyre nagyobb jelentőségú.

Célkitüzés: Magyar és külföldi hallgatók körében folytatott vizsgálatunk fókuszában a beilleszkedési folyamatoknak, valamint az interkulturális kompetencia és érzékenység kialakulásának és fejlődésének vizsgálata állt, a Pécsre érkező mintegy 60 különböző kultúra, valamint a magyar befogadó közeg vonatkozásában egyaránt. Kutatásunk során többek között arra kerestünk választ, hogy az eredeti és a befogadó kultúra közötti különbségek mely területeken nyilvánulnak meg a leginkább, illetve egy másik kultúrához történő alkalmazkodás során milyen beilleszkedést lassító vagy támogató tényezők tárhatók fel.

Módszer: Kutatásunkban kvantitatív és kvalitatív módszereket alkalmaztunk, önkitöltéses kérdőíves felmérés, valamint fókuszcsoportos interjúk formájában. A PTE ÁOK német, angol és magyar nyelvú általánosorvos-képzésében részt vevő hallgatókat a 2010 és 2018 közötti időszak tavaszi szemesztereiben saját fejlesztésú, anonim, önkéntesen kitölthető kérdőívvel kerestük meg (a kitöltött kérdőívek száma: n = 13084 kérdoóiv). A kérdőíveket három tanévben hét, félig strukturált fókuszcsoportos interjúval egészítettük ki ( $\mathrm{n}=92$ fó).

Eredmények: A hazánkba érkező külföldi orvostanhallgatók számára a befogadó közeghez való alkalmazkodást tekintve a kapcsolódás elsősorban a szocializációs, nyelvi, kommunikációs különbségek miatt bizonyult kihívásnak. Megállapítható azonban, hogy a képzési idő előrehaladtával a különbözőségekbőll fakadó nehézségek csökkentek, így a hallgatók egyre inkább képessé váltak az etnorelatív irányba történő elmozdulásra, valamint a multikulturális közeg pozitív aspektusainak értékelésére.

Következtetések: A multikulturális környezetben folytatott tanulmányok alatt a kultúraközi kapcsolódási pontok és együttmúködések kialakulása és fejlődése lehetővé teszi és támogatja az interkulturális kompetencia elsajátítását, annak minden résztvevője számára, akár az egyetemi képzésen túlmutatóan, a későbbi orvosi pályát tekintve is.

Orv Hetil. 2021; 162(25): 978-987.

Kulcsszavak: nemzetköziesítés, hallgatói mobilitás, kulturális különbségek, interkulturális kompetenciafejlesztés

\section{Accepting cultural differences in the integration of foreign medical students}

Introduction: In the increasingly multicultural social environment of the 21 st century, intercultural knowledge as a social skill is gradually becoming a key competence. One of the possible areas of acquiring this competence is international student mobility, which is of increasing importance worldwide, including Hungary.

Objective: The focus of our study was to examine integration processes and the development and improvement of intercultural competence and sensitivity among Hungarian and international students, both in relation to the approximately 60 different cultures arriving in Pécs and in relation to the Hungarian host environment. In the course of our research, we sought - among other factors - areas, in which the differences between the original and the host culture are the most prominent, and we aimed at identifying those factors that are slowing down or supporting the integration during the adaptation period to another culture.

Method: In our research, we used both quantitative and qualitative methods, in the form of a self-administered questionnaire and focus group interviews. General medical students of the University of Pécs studying in the German-, English- and Hungarian-language programmes participated in the survey during the spring semesters of the aca- 
demic years between 2010 and 2018. We used our self-developed questionnaires (number of completed questionnaires: $n=13084$ ), which were filled in on a voluntary basis and anonymity was ensured. The questionnaires were supplemented with seven semi-structured focus group interviews over three academic years ( $\mathrm{n}=92$ students).

Results: Regarding the adaptation to the host environment of foreign medical students studying in Hungary, relationship building arising from socialization, language and communication differences, proved to be a challenge. However, it can be stated that as the training time progressed, the difficulties arising from the differences decreased, so that the students gradually became more able to move towards an ethno-relative direction and evaluated the positive aspects of the multicultural environment.

Conclusion: During studies in a multicultural university environment, the emergence and development of intercultural connections and collaborations enable and support the acquisition of intercultural competence for all of the students, which will be of great benefit for them, even beyond the university, in their future medical career.

Keywords: medical education, internationalisation, student mobility, cultural differences, intercultural competence development

Faubl N, Pótó Zs, Marek E, Birkás B, Füzesi Zs, Németh T. [Accepting cultural differences in the integration of foreign medical students]. Orv Hetil. 2021; 162(25): 978-987.

(Beérkezett: 2020. november 6.; elfogadva: 2020. december 24.)

\section{Rövidítések}

PTE ÁOK = Pécsi Tudományegyetem, Általános Orvostudományi Kar; SD = standard deviáció

Az egészségügy múködését és annak minőségét jelentős mértékben az ágazatban dolgozó szakemberek határozzák meg, ezért különösen fontos, hogy az egészségügy humánerőforrásaival kapcsolatban a jelenre és a jövőre vonatkozóan is rendelkezzünk információkkal.

$\mathrm{Az}$ interkulturális kompetenciának az egészségügyi ellátásban elengedhetetlen fontosságára és szükségességére számos tanulmány hívta fel a figyelmet az elmúlt két évtized során [1-5]. A társadalmakban tapasztalható szociokulturális különbségek, valamint az általuk egyre összetettebbé váló kontextusok - mint például az egészség és a betegség, a tünetek és a lehetséges gyógymódok kulturális különbségei [6-8], az egészségügyi ellátásba vetett bizalom, a kisebbségi csoportokhoz tartozó páciensek [9-11] vagy a migrációs jelenségekből adódó multikulturális közeg [12] - gyakran jelennek meg olyan helyzetekben, amelyekben a páciens és az ellátást nyújtó eltérő kulturális háttérrel rendelkezik, találkozásukra pedig adott esetben egy harmadik kultúrában kerül sor. Mindez szükségessé teszi az egészségügyben dolgozó ápolószemélyzet és az orvosok interkulturális kompetenciáinak fejlesztését célzott programok és tréningek formájában, lehetőség szerint már az egészségügyi képzés (szakképzés, felsőfokú tanulmányok) keretében [13-15]. Fontos hangsúlyozni, hogy a klinikai gyakorlatban a kulturális különbségek érzékelése, melyet gyakran interkulturális konfliktushelyzetekként definiálnak, nem redukálható a nyelvi és vallási különbségek dimenzióira. Az interkulturális kompetencia egyfajta tapasztalati készség, mely elsősorban nem a más kultúrákkal kapcsolatos beható ismeretek előzetes megszerzésé- vel, sokkal inkább a participáció [16, 17] során kialakuló szociális, személyiségbeli, kommunikatív és cselekvési kompetenciákon keresztül sajátítható el [18, 19]. Ezek közül is kiemelten fontos a saját értékekkel, magatartásés gondolkodásmóddal kapcsolatos tudatosság, a cselekedetekkel összefüggő reflexió képessége [20], a perspektíva- és paradigmaváltás készsége, az etnocentrizmus kerülése és a kulturális relativizmus felé történő elmozdulás $[21,22]$.

Az interkulturális kompetencia vizsgálatának fókuszában többek között maga a folyamat, az interkulturális tudás és érzékenység fejlődése áll [23-29]. Bennett interkulturális érzékenység fejlődésével foglalkozó modellje $[24,30]$ szerint szakaszos fejlődésről van szó, mely két nagyobb egységre tagolható: etnocentrikus és etnorelatív fázisra. Az előbbiben az érintett személy mintegy a saját kultúrájának szemüvegén keresztül nézi új környezetét, míg a következóben - individuálisan eltérő hoszszúságú idő eltelte után - képessé válhat saját kultúrája látásmódjától függetlenedve, önmagában látni és értelmezni a befogadó kultúra jelenségeit. A két fázison belül összesen hat szakaszban, az elutasítástól akár egészen az integrációig eljuthat a korábban esetleg teljesen ismeretlen kultúrába érkezett személy. Az interkulturális érzékenység kialakulásának folyamatjellege mellett Deardorff modellje $[20,29]$ arra is felhívja a figyelmet, hogy az interkulturális kompetencia négy dimenzióból tevődik össze: a támogató attitûd, az átfogó (a saját kultúrát is magában foglaló) kulturális tudás, az interkulturális témákra történő reflektálás, valamint a konstruktív cselekvés képessége. Minél pozitívabb az interkulturalitással kapcsolatos attitûd, annál több tudás és készség kerül elsajátításra. Emellett minél gyakoribb az interkulturális helyzetekkel kapcsolatos reflexió és konstruktív cselekvés, annál magasabb szintú interkulturális kompetencia érhető el. E négy dimenzió kölcsönös és folyamatos egy- 
másra hatása egyfajta tanulási spirált alkot, ami egyben rávilágít az interkulturális kompetencia elsajátításának folyamatosságára is.

Globalizálódó világunkban a multikulturális társadalmi közeg egyre inkább mindennapi valósággá válik, ebből következően az interkulturális tudás mint társadalmi készség is fokozott mértékben válik kulcskompetenciává [31]. E kompetencia elsajátításának egyik lehetséges területe a nemzetközi hallgatói mobilitás, mely világszerte egyre nagyobb jelentőségü. A jelenséget vizsgáló szerzők kiemelik, hogy a nemzetközi mobilitásban részt vevő hallgatók az elsajátított tudás mellett interkulturális kompetenciákkal is gazdagodnak [32-35]. A részleges külföldi tartózkodást lehetővé tevő, kreditmobilitásra alkalmas programok mellett $[36,37]$ továbbra is a teljes tanulmányi időt átfogó diplomamobilitás számít jelentősebbnek, mind a résztvevők arányát, mind pedig az ebből származó gazdasági és kulturális hatásokat nézve. Magyarországon a teljes idejü képzéseket jelentő diplomamobilitást tekintve az orvosképzés a legnépszerúbb a külföldi hallgatók körében, mely jelenleg minden magyarországi orvoskaron egyre növekvő hallgatói létszámmal valósul meg.

A Pécsi Tudományegyetem Általános Orvostudományi Karának (PTE ÁOK) nemzetközi közegében több mint hatvan nemzet diákjai tanulnak, három képzési nyelven. Bár az interkulturális tudás megszerzésének lehetősége nem elsődleges célként definiálódik a tanulmányok helyszínének kiválasztásakor, az idő előrehaladtával mind a befogadó közeg, mind pedig az idegen nyelvú képzés diákjai körében kialakul az interkulturális kulcskompetencia megszerzésének lehetősége.

A külföldön tanulás az egyetemi tanulmányokkal egyidejúleg egy idegen országba, városba, kultúrába, hallgatói környezetbe való beilleszkedés szempontjából is kihívást jelent $[38,39]$. Ez jelentősen megterheli a hallgatókat, különösen kezdetben, hiszen az új környezethez való alkalmazkodás folyamatos megküzdést és adaptációt igényel tólük [40-43].

Jelen kutatásunkban egyebek mellett azt vizsgáltuk, hogy a Magyarországon/Pécsett tanuló külföldi és magyar hallgatók milyen, multikulturális egyetemi közegben zajló beilleszkedési folyamatokról számoltak be, illetve hogyan látják a tanulmányaik során elsajátított extrakurrikuláris kompetenciáikat, különös tekintettel az interkulturális készségek fejlődésére.
Kutatásunkhoz - többek között - a következő kérdéseket fogalmaztuk meg:

- Az eredeti és a befogadó kultúra közötti különbségek mely területeken nyilvánulnak meg a leginkább?

- Egy másik kultúrához történő alkalmazkodás során milyen, a beilleszkedést lassító vagy támogató tényezók tárhatók fel?

Hipotézisünk szerint a külföldi hallgatók alkalmazkodási és beilleszkedési folyamata az itt töltött idő során - a hasonlóságok és különbségek, valamint a lassító és támogató tényezők megtapasztalása mellett - az etnorelatív fázis irányába mutat, mely lehetôséget teremt az interkulturális érzékenység és kompetencia fejlődésére.

\section{Módszer}

A multikulturális környezet interkulturális hatásával kapcsolatos kutatásunkban kvantitatív és kvalitatív módszereket egyaránt alkalmaztunk, önkitöltéses kérdőíves felmérés, valamint fókuszcsoportos interjúk formájában. A saját fejlesztésû kérdőívvel végzett vizsgálatokat (az etikai engedély száma: PTE 4838) 2010-ben a német nyelvű képzés hallgatóival kezdtük. A kutatást a későbbiekben kiterjesztettük az angol, majd a magyar nyelvű képzés hallgatóira is, mivel a kapott eredmények alapján hosszabb távon a beilleszkedési folyamatoknak a multikulturális közeg szempontjából történő átfogó vizsgálata látszott a leginkább célravezetőnek. Az önkitöltéses kérdőíveket minden adatfelvételi év esetében első alkalommal online formában, a sikeres egyetemi felvételre vonatkozó elektronikus értesítés részeként, csatolt link formájában juttattuk el, illetve a Pécsre érkezésüket követően, az orientációs nap keretében osztottuk ki a felvett hallgatóknak. További kérdőíves felmérésre minden tanévben a tavaszi szemeszter során került sor, az adott évfolyam egyik kötelező egyetemi tantárgyi (például anatómia, élettan, közegészségtan, gyógyszertan, belgyógyászat) óráját követően, az oktató kollégák támogatásával és bevonásával. A tanórák a legtöbbször szemináriumokat és gyakorlati órákat jelentettek, a vizsgálatban történő részvétel minden alkalommal önkéntes alapon történt. A német, angol és magyar képzésben részt vevő hallgatókat tanulmányaik során összesen hat alkalommal kérdeztük meg annak érdekében, hogy az egyetemi évek alatt bekövetkező változásokat figyelemmel kísérhessük (1. táblázat).

1. táblázat |A vizsgált populáció és a visszaérkezett kérdőívek összefoglaló adatai

\begin{tabular}{|c|c|c|c|c|c|c|c|c|c|c|}
\hline \multirow[t]{2}{*}{ Évfolyam } & \multicolumn{3}{|c|}{ Német nyelvű képzés } & \multicolumn{3}{|c|}{ Angol nyelvú képzés } & \multicolumn{3}{|c|}{ Magyar nyelvủ képzés } & \multirow{2}{*}{$\begin{array}{c}\text { Összes válaszadó } \\
\text { (fó) }\end{array}$} \\
\hline & $\begin{array}{l}\text { Hallgatók } \\
\text { (fö) }\end{array}$ & $\begin{array}{l}\text { Válaszadók } \\
\text { (fö) }\end{array}$ & $\begin{array}{l}\text { Válasz- } \\
\text { adók } \\
(\%)\end{array}$ & $\begin{array}{l}\text { Hallgatók } \\
\text { (fö) }\end{array}$ & $\begin{array}{l}\text { Válaszadók } \\
\text { (fö) }\end{array}$ & $\begin{array}{l}\text { Válasz- } \\
\text { adók } \\
(\%)\end{array}$ & $\begin{array}{l}\text { Hallgatók } \\
\text { (fó) }\end{array}$ & $\begin{array}{l}\text { Válaszadók } \\
\text { (fö) }\end{array}$ & $\begin{array}{l}\text { Válasz- } \\
\text { adók } \\
(\%)\end{array}$ & \\
\hline Elsőéves & 1279 & 1023 & 79,9 & 1061 & 733 & 69,0 & 791 & 722 & 91,2 & 2478 \\
\hline Másodéves & 1041 & 961 & 92,3 & 843 & 704 & 83,5 & 1020 & 916 & 89,8 & 2581 \\
\hline Felsőbb éves & 896 & 721 & 80,4 & 636 & 497 & 78,1 & 611 & 504 & 82,4 & 1722 \\
\hline Végzôs & 119 & 117 & 98,3 & 291 & 288 & 98,9 & 254 & 254 & 100,0 & 659 \\
\hline
\end{tabular}


A nyolc éven keresztül folytatott vizsgálat során összesen 13084 darab online és papíralapon kitöltött kérdőív érkezett vissza kutatócsoportunkhoz. A kérdőíves felmérés válaszadóinak száma $50 \%$ feletti kitöltöttségi arányt mutatott mindhárom képzési nyelv, az összes évfolyam minden kiválasztott kötelező tantárgya, valamint minden adatfelvételi időszak esetében. A mintanagyság a német hallgatók esetében 5285, az angol nyelvü képzés esetében 4225, a magyar hallgatóknál pedig 3574 kitöltött kérdőívet jelentett (egy hallgató több idődimenzióban is részt vett a felmérésben). A vizsgálatban részt vevő hallgatók életkora a magyar programban volt a legalacsonyabb, 19,3 év (SD = 1,6). Az idegen nyelvü képzés vizsgálatba került hallgatóinak átlagéletkora a várakozásoknak megfelelően a magyar hallgatókhoz képest magasabb volt: a német nyelvű képzésben 20,5 év (SD = 2,3), az angol nyelvü, állampolgárság és nemzetiség szempontjából heterogén csoportban 21,0 év (SD = 3,6). Az angol nyelvű képzés hallgatói között az iráni $(16,8 \%)$ és a norvég (14,9\%) állampolgárságú résztvevők jelentettek nagyobb homogén csoportot, a hallgatók jelentősebb része mintegy hatvan további országból érkezett.

Az önkitöltéses, visszaazonosításra nem alkalmas kérdőíves vizsgálat jellegéből adódóan reprezentatív mintáról nem beszélhetünk, így a felmérés eredményei szigorúan véve nem alkalmasak a teljes vizsgálati populációval kapcsolatos általánosításra. Vizsgálatunk korlátját a megismételt vizsgálatok ellenére hiányzó konkrét beazonosíthatóság és követhetőség jelenti. Ezzel együtt, a mindenkori válaszadói arány az adatfelvételek során mindvégig magas volt, a válaszadók közül jelentős hallgatói csoportok nem maradtak ki, így feltételezzük, hogy a kutatási eredmények érvényesnek tekinthetők a vizsgált hallgatói populációra.

Kérdőíves kutatásunk váza és témakörei a következők voltak: demográfiai adatok, korábbi külföldi és interkulturális tapasztalatok, általános közérzet multikulturális környezetben, az eddigi interkulturális tapasztalatok, valamint kellemetlen helyzetek, a beilleszkedés és alkalmazkodás kérdései Pécsett és a származási országban, kommunikáció és nyelvhasználat multikulturális környezetben.

Kérdőíves kutatásunkat annak lezárását követően a félig strukturált fókuszcsoportos interjúkkal is kiegészítettük, ezáltal a csoportszintú interakciók során lehetôségünk nyílt a kérdések alaposabb, több szempontból történő megvitatására is. Mivel az interkulturális kompetencia kialakulásában és fejlődésében a multikulturális környezet erős befolyással bír, a vélemények és tapasztalatok is gyakran csoportszintűek, ezért a fókuszcsoportos interjúk jól tükrözhetik az egyes beállítódásokkal és véleményekkel kapcsolatos attitűdöket, megvitatásuk által pedig felszínre kerülhetnek olyan meglátások, melyekre a kérdőíves vizsgálatok során nem derült volna fény. A hét alkalommal lefolytatott fókuszcsoport-vizsgálatok összes résztvevőjének száma 92 fő volt, az egyes csoportok létszáma 8 és 15 fó között alakult. A válaszadók több mint fele a német és az angol képzés hallgatói közül került ki (összesen 51 fó). A fókuszcsoportos interjúk részvevőinek életkora összhangban állt a kérdőíves vizsgálat válaszadóinak demográfiai adataival: az angol és német nyelvű képzésben részt vevő hallgatók átlagéletkora a magyar hallgatókhoz képest magasabb volt. Az interjúk résztvevői között szinte egyenlő arányban voltak jelen a férfiak és a nők (45 férfi és 47 nő). A résztvevők több mint fele az idegen nyelvü, a német és az angol képzés hallgatói közül került ki (összesen 51 fó), mely megoszlás A férfi-nő arány és az évfolyamok reprezentációja a fókuszcsoportok választott kereteinek megfelelő volt. A fókuszcsoportos interjúkra a PTE ÁOK választható kurzusainak keretén belül, az egyes tanórákat követően került sor, összesen hét alkalommal, önkéntes részvétellel: ebből öt alkalommal olyan idegen nyelven tartott kurzus után, melyre a német, az angol és a magyar nyelvű képzés hallgatói is jelentkezhettek, két alkalommal pedig a magyar nyelvű képzés számára meghirdetett választható kurzusokat követően. A tantárgyak a PTE ÁOK Magatartástudományi Intézete által meghirdetett választható kurzusok voltak, melyekre bármelyik évfolyamban tanuló hallgatók jelentkezhettek, megkötés és előfeltétel nélkül, így lehetőség nyílt a vizsgált populáció lefedésére. A 50-70 perc hosszúságú, fókuszcsoportos interjúk vezérfonalát korábbi feltáró vizsgálataink, valamint a kérdöív kiválasztott témakörei alapján állítottuk össze. Az interjú-vezérfonal témái a következők voltak: általános közérzet multikulturális környezetben, a multikulturális környezet érintkezési pontjai és kihívásai, multikulturális környezettel kapcsolatos eddigi pozitív és negatív tapasztalatok, kellemetlen helyzetek. A beszélgetések hangfelvételét a résztvevők beleegyezésével rögzítettük, ebből az elemzés alapjául szolgáló jegyzőkönyvek készültek.

A jelen tanulmányban a külföldi hallgatók és a befogadó magyar kultúra közötti, adott szempontok (például életmód és életstílus, munkához való viszony, kommunikáció stb.) mentén feltárt különbségekre, valamint a befogadó kultúrához történő alkalmazkodást segítő, illetve nehezítő (a magyar nyelvtudást érintő, gondolkodás-, magatartás- és szokásbeli, infrastrukturális és ügyintézési különbségek stb.) tényezőkre vonatkozó eredményeket mutatjuk be.

Hipotézisünknek megfelelően a kérdőíves vizsgálatban húsz felsorolt szempont közül jelölték a válaszadók azt az ötöt, amelyet a leginkább jellemzőnek éreztek az egyes kérdések vonatkozásában (a húsz szempont egy előzetes, még nyitott kérdéseket tartalmazó kérdőíves vizsgálat, majd az azt követő tesztelési fázis során került kialakításra). A bemutatott táblázatokban az egyes területekre adott jelölések aránya látható. Jelen tanulmányunkban a saját és a magyar kultúra között érzékelt különbségek (2. táblázat), valamint az alkalmazkodás szempontjából legegyszerúbb és legnehezebb dimenziók (3. és 4. táblázat) képzési formák és évfolyam szerinti bontásban kerülnek bemutatásra és elemzésre, melyhez a 
2. táblázat | Különbségek a saját és a magyar kultúra között - összesített eredmények (angol és német nyelvü képzési program)

\begin{tabular}{|c|c|c|c|c|c|c|}
\hline $\begin{array}{l}\text { Dimenziók képzési } \\
\text { programok szerint } \\
\text { (n = jelölések száma) }\end{array}$ & & 1. évfolyam & 2. évfolyam & $\begin{array}{c}\text { Felsőbb } \\
\text { évfolyamok }\end{array}$ & Végzősök & $\begin{array}{l}\mathrm{p} \\
\text { 1. évfolyam } \\
\text { - végzösök }\end{array}$ \\
\hline \multirow{2}{*}{$\begin{array}{l}\text { Magatartás- és gondolko- } \\
\text { dásmód }\end{array}$} & Német nyelvü képzés & $7,3 \%(\mathrm{n}=5789)$ & $6,9 \%(n=3546)$ & $6,9 \%(n=4672)$ & $-(\mathrm{n}=2817)$ & - \\
\hline & Angol nyelvű képzés & $7,0 \%(\mathrm{n}=3899)$ & $6,7 \%(n=4466)$ & $8,4 \%(n=3389)$ & $7,6 \%(\mathrm{n}=1340)$ & 0,209 \\
\hline \multirow[t]{2}{*}{ Életmód, életstílus } & Német nyelvú képzés & $7,3 \%(\mathrm{n}=5789)$ & $6,4 \%(n=3546)$ & $-(\mathrm{n}=4672)$ & $-(\mathrm{n}=2817)$ & - \\
\hline & Angol nyelvű képzés & $9,3 \%(\mathrm{n}=3899)$ & $9,0 \%(\mathrm{n}=4466)$ & $7,8 \%(\mathrm{n}=3389)$ & $9,0 \%(\mathrm{n}=1340)$ & 0,371 \\
\hline Infrastruktúra, bürokrácia & Német nyelvű képzés & $6,6 \%(n=5789)$ & $6,4 \%(n=3546)$ & $6,8 \%(\mathrm{n}=4672)$ & $-(\mathrm{n}=2817)$ & - \\
\hline Szociális körülmények & Német nyelvú képzés & $8,2 \%(\mathrm{n}=5789)$ & $8,3 \%(\mathrm{n}=4466)$ & $7,3 \%(\mathrm{n}=4672)$ & $-(\mathrm{n}=2817)$ & - \\
\hline \multirow[t]{2}{*}{ Közélet } & Német nyelvű képzés & $6,9 \%(n=5789)$ & $7,6 \%(n=3546)$ & $7,4 \%(\mathrm{n}=4672)$ & $10,1 \%(\mathrm{n}=2817)$ & 0,000 \\
\hline & Angol nyelvű képzés & $-(\mathrm{n}=3899)$ & $-(\mathrm{n}=4466)$ & $-(\mathrm{n}=3389)$ & $8,1 \%(\mathrm{n}=1340)$ & - \\
\hline Közlekedési szokások & Német nyelvű képzés & $-(n=5789)$ & $-(\mathrm{n}=3546)$ & $6,1 \%(\mathrm{n}=4672)$ & $-(\mathrm{n}=2817)$ & - \\
\hline $\begin{array}{l}\text { Szabadidős lehetőségek, } \\
\text { partik }\end{array}$ & Angol nyelvű képzés & $-(\mathrm{n}=5789)$ & $-(\mathrm{n}=4466)$ & $-(\mathrm{n}=4672)$ & $9,4 \%(\mathrm{n}=2817)$ & - \\
\hline \multirow[t]{2}{*}{ Öltözködési kultúra } & Német nyelvű képzés & $-(\mathrm{n}=5789)$ & $-(\mathrm{n}=3546)$ & $-(\mathrm{n}=4672)$ & $20,4 \%(n=2817)$ & - \\
\hline & Angol nyelvű képzés & $6,6 \%(n=3899)$ & $7,1 \%(n=4466)$ & $6,9 \%(\mathrm{n}=4672)$ & $-(\mathrm{n}=2817)$ & - \\
\hline Munkamorál & Német nyelvű képzés & $-(\mathrm{n}=5789)$ & $-(\mathrm{n}=3546)$ & $-(n=4672)$ & $14,0 \%(\mathrm{n}=2817)$ & - \\
\hline Nemzeti büszkeség & Német nyelvú képzés & $-(\mathrm{n}=5789)$ & $-(\mathrm{n}=3546)$ & $-(n=4672)$ & $10,7 \%(\mathrm{n}=2817)$ & - \\
\hline Árak, vásárlási lehetőségek & Angol nyelvű képzés & $8,1 \%(n=3899)$ & $7,3 \%(\mathrm{n}=4466)$ & $7,0 \%(\mathrm{n}=4672)$ & $6,3 \%(\mathrm{n}=2817)$ & 0,017 \\
\hline Lakhatás & Angol nyelvű képzés & $6,3 \%(n=3899)$ & $-(\mathrm{n}=4466)$ & $-(\mathrm{n}=4672)$ & $-(\mathrm{n}=2817)$ & - \\
\hline Gasztronómia & Angol nyelvű képzés & $-(n=3899)$ & $6,5 \%(n=4466)$ & $-(\mathrm{n}=4672)$ & $8,4 \%(\mathrm{n}=2817)$ & - \\
\hline Kommunikáció & Angol nyelvű képzés & $-(\mathrm{n}=3899)$ & $-(\mathrm{n}=4466)$ & $6,3 \%(\mathrm{n}=4672)$ & $-(\mathrm{n}=2817)$ & - \\
\hline
\end{tabular}

Az adatelemzéshez a tanulmányi idő eltelte során számszerúsített arányok egyezőségét vizsgáltuk az erre specializált standard normális eloszlású próbafüggvény segítségével: $z_{e m p}=\left[\left(p_{1}-p_{2}\right)-\pi\right] /\left(S_{p_{1}-p_{2}}\right)$, amelyben a $\pi$-t 0 -nak tekintjük, mivel kiinduló feltételezésünk az, hogy a két vizsgált arány megegyezik, az $S_{p_{1}-p_{2}}$ egyfajta közös, az elemszámot is felhasználó becsült, súlyozott szórás [44]. Ha az adott szempont a kérdőívben szereplő összes dimenzió között nem szerepelt az első öt hely egyikén, akkor nem tüntettük fel a táblázatokban. Emellett nem tudtunk p-értéket képezni ott, ahol vagy a végzős, vagy a kezdő évfolyam jelölési aránya hiányzik.

tanulmányi idő eltelte során számszerüsített arányok egyezőségét vizsgáltuk az erre specializált standard, normális eloszlású próbafüggvény segítségével [44]. Elemzéseinket az SPSS Statistics program 26.0-s verziójával (IBM, Armonk, NY, Egyesült Államok) végeztük.

\section{Eredmények}

A multikulturális környezet interkulturális hatását feltáró, kérdőíves és fókuszcsoportos vizsgálatunk eredményeiből az alábbiakban azon releváns dimenziók szignifikáns eredményeit mutatjuk be, melyek az interkulturális kompetencia fejlődését befolyásolhatják.

\section{A kvantitatív kérdőíves vizsgálatok eredményei}

\section{Az evedeti és a befogadó kultúra közötti különbségek}

A saját és a célkultúra közötti különbségek tekintetében azt vizsgáltuk nyelvi csoportonként, hogy az erre a kérdésre érkezett összes jelölés mekkora hányada esett az általunk felsorolt területekre egyenként (2. táblázat). Megvizsgáltuk, hogy a végzősök és a kezdő évfolyamok jelölési aránya között van-e érdemi, statisztikailag is mérhető különbség. Az eredmények alapján megállapítható, hogy a német nyelvú képzésben a tanulmányi idő előrehaladtával növekedés volt tapasztalható a közélettel kapcsolatban érzékelt különbségeket tekintve, másképpen fogalmazva: a felsőbb évesek között érdemben nagyobb volt azon hallgatók aránya, akik a saját és a magyar kultúrának a közélettel kapcsolatos eltéréseit érdemben érzékelték. Figyelemre méltó, hogy bizonyos tényezőket a felsőbb éves hallgatók már nem említettek (például az életmóddal, életstílussal kapcsolatos különbségek), más - a befogadó kultúrára jellemző szempontok pedig csak a végzősöknél jelentek meg, mint például a munkához való hozzáállás vagy a nemzeti büszkeség. A tanulmányi idő előrehaladtával bizonyos tényezők különbségének érzékelése a német mellett az angol nyelvű hallgatók körében is megszűnik (például lakhatás, öltözködés), miközben más szempontok, mint például a közéleti vagy a kommunikációs különbségek érzékelése, a felsőbb évfolyamokon jelennek meg. 
3. táblázat $\mid$ Az alkalmazkodás szempontjából a legegyszerúbb - összesített eredmények (minden képzési program)

\begin{tabular}{|c|c|c|c|c|c|c|}
\hline $\begin{array}{l}\text { Dimenziók képzési } \\
\text { programok szerint } \\
\text { (n = jelölések száma) }\end{array}$ & & 1. évfolyam & 2. évfolyam & $\begin{array}{l}\text { Felsőbb } \\
\text { évfolyamok }\end{array}$ & Végzősök & $\begin{array}{l}\stackrel{p}{1 .} \text { évfolyam } \\
\text { - végzösök }\end{array}$ \\
\hline \multirow{3}{*}{$\begin{array}{l}\text { Egyetemi tanulmányok, } \\
\text { egyetemi élet }\end{array}$} & Német nyelvú képzés & $24,2 \%(\mathrm{n}=2522)$ & $25,2 \%(\mathrm{n}=2509)$ & $23,3 \%(\mathrm{n}=1993)$ & $17,1 \%(n=469)$ & 0,000 \\
\hline & Angol nyelvű képzés & $24,4 \%(\mathrm{n}=1279)$ & $21,5 \%(\mathrm{n}=1236)$ & $23,1 \%(\mathrm{n}=986)$ & $18,2 \%(\mathrm{n}=787)$ & 0,000 \\
\hline & Magyar nyelvű képzés & $24,1 \%(\mathrm{n}=1135)$ & $24,6 \%(\mathrm{n}=1409)$ & $25,7 \%(\mathrm{n}=829)$ & $20,4 \%(\mathrm{n}=515)$ & 0,051 \\
\hline \multirow[t]{3}{*}{ Mindennapi élet } & Német nyelvű képzés & $14,8 \%(\mathrm{n}=2522)$ & $-(\mathrm{n}=2509)$ & $14,1 \%(\mathrm{n}=1993)$ & $12,8 \%(\mathrm{n}=469)$ & 0,133 \\
\hline & Angol nyelvű képzés & $17,0 \%(\mathrm{n}=1279)$ & $16,5 \%(n=1236)$ & $13,5 \%(\mathrm{n}=986)$ & $16,3 \%(\mathrm{n}=787)$ & 0,323 \\
\hline & Magyar nyelvű képzés & $19,0 \%(\mathrm{n}=1135)$ & $18,7 \%(\mathrm{n}=1409)$ & $19,1 \%(\mathrm{n}=829)$ & $17,1 \%(\mathrm{n}=515)$ & 0,174 \\
\hline Gasztronómia & Német nyelvú képzés & $11,5 \%(\mathrm{n}=2522)$ & $12,9 \%(\mathrm{n}=2509)$ & $14,8 \%(\mathrm{n}=1993)$ & $11,7 \%(n=469)$ & 0,452 \\
\hline \multirow[t]{2}{*}{ Lakhatás } & Német nyelvű képzés & $17,3 \%(\mathrm{n}=2522)$ & $17,6 \%(\mathrm{n}=2509)$ & $16,9 \%(\mathrm{n}=1993)$ & $12,2 \%(\mathrm{n}=469)$ & 0,003 \\
\hline & Angol nyelvű képzés & $11,8 \%(\mathrm{n}=1279)$ & $10,9 \%(\mathrm{n}=1236)$ & $12,5 \%(\mathrm{n}=986)$ & $12,5 \%(\mathrm{n}=787)$ & 0,330 \\
\hline \multirow[t]{2}{*}{ Árak, vásárlási lehetőségek } & Német nyelvű képzés & $13,1 \%(\mathrm{n}=2522)$ & $12,9 \%(\mathrm{n}=2509)$ & $13,1 \%(\mathrm{n}=1993)$ & $11,5 \%(\mathrm{n}=469)$ & 0,169 \\
\hline & Angol nyelvű képzés & $15,1 \%(\mathrm{n}=1279)$ & $21,8 \%(\mathrm{n}=1236)$ & $19,7 \%(\mathrm{n}=986)$ & $15,8 \%(\mathrm{n}=787)$ & 0,341 \\
\hline \multirow[t]{2}{*}{ Alkalmazkodás } & Angol nyelvű képzés & $10,4 \%(\mathrm{n}=1279)$ & $10,4 \%(\mathrm{n}=1236)$ & $11,5 \%(\mathrm{n}=986)$ & $-(\mathrm{n}=787)$ & - \\
\hline & Magyar nyelvű képzés & $-(\mathrm{n}=1135)$ & $8,1 \%(n=1409)$ & $8,1 \%(n=829)$ & $8,2 \%(\mathrm{n}=515)$ & - \\
\hline $\begin{array}{l}\text { Szabadidős tevékenység, } \\
\text { partik }\end{array}$ & Angol nyelvű képzés & $-(\mathrm{n}=1279)$ & $-(\mathrm{n}=1236)$ & $-(\mathrm{n}=986)$ & $8,8 \%(\mathrm{n}=787)$ & - \\
\hline Idegen nyelvek használata & Magyar nyelvű képzés & $14,5 \%(\mathrm{n}=1135)$ & $15,3 \%(\mathrm{n}=1409)$ & $14,8 \%(\mathrm{n}=829)$ & $16,9 \%(\mathrm{n}=515)$ & 0,109 \\
\hline $\begin{array}{l}\text { Az ország és lakóinak } \\
\text { megismerése }\end{array}$ & Magyar nyelvű képzés & $10,5 \%(\mathrm{n}=1135)$ & $12,6 \%(\mathrm{n}=1409)$ & $11,1 \%(\mathrm{n}=829)$ & $12,6 \%(\mathrm{n}=515)$ & 0,100 \\
\hline Integráció & Magyar nyelvű képzés & $9,2 \%(\mathrm{n}=1135)$ & $-(\mathrm{n}=1409)$ & $-(\mathrm{n}=829)$ & $-(\mathrm{n}=515)$ & - \\
\hline
\end{tabular}

\section{Alkalmazkodás egy másik kultúrához - a beilleszkedést lassitó vagy támogató tényezőh}

A befogadó kultúrához való alkalmazkodást vizsgálva rákérdeztünk, hogy az idegen nyelvű képzés hallgatói mely területeket érezték a legegyszerúbbnek (3. táblázat) és a legnehezebbnek (4. táblázat) ebból a szempontból.

A német nyelvü képzés válaszadói az alkalmazkodás szempontjából az egyetemi tanulmányokat, az egyetemi életet és a lakhatást tartották a leginkább egyszerúnek, mégpedig a tanulmányi idő előrehaladtával csökkenést mutatva. Az alkalmazkodás szempontjából folyamatosan egyszerúnek ítélték még a hétköznapi életet, az árak, a vásárlási lehetőségek és a gasztronómia tényezőit. Az angol nyelvü képzés válaszadói - a német hallgatókhoz hasonlóan - az alkalmazkodás szempontjából a leginkább egyszerúnek az egyetemi tanulmányokat és az egyetemi életet tartották, a tanulmányi idő előrehaladtával csökkenést mutatva. Emellett folyamatosan „egyszerünek” ítélték még a hétköznapi élet, a lakhatás, az árak, a vásárlási lehetőségek, valamint az alkalmazkodás egyéb tényezőit. A német nyelvú képzéssel szemben a gasztronómia nem jelent meg az öt leggyakrabban jelölt tényező között az angol nyelvú hallgatóknál, míg a szabadidős lehetőségeket csak a végzősök ítélték az alkalmazkodás szempontjából egyszerúnek. Az idegen nyelvű képzés hallgatóihoz hasonlóan megkérdeztük a magyar ballgatókat is, hogy a nemzetközi közeghez való alkalmazkodást tekintve mit érzékeltek a legkönnyebbnek. Az eredmények alapján megállapítható, hogy a magyar hallgatók számára szintén a nemzetközi közegben folytatott egyetemi tanulmányok és egyetemi élet számított a leginkább egyszerúnek. Másodévtől jelenik meg az alkalmazkodás szempontja, miközben a befogadást és az integrációt csak az elsőévesek jelölték egyszerúnek.

Mind az idegen nyelvú, mind a magyar nyelvű képzés hallgatóit megkérdeztük azzal kapcsolatban is, hogy az alkalmazkodás szempontjából mit érzékeltek a legnehezebbnek. A német nyelvü képzés válaszadói a tanulmányok ideje alatt, csökkenő tendencia mellett, végig a befogadó kultúra nyelvét jelölték meg a legnehezebbnek. A nehézség ellenére hasonlóan csökkenő tendenciát mutatott a hazától való távolság szempontja. A szociális körülményekkel kapcsolatos nehézségek a tanulmányi idő elörehaladtával növekedést mutattak, az infrastruktúra és a bürokrácia szempontjához hasonlóan. Az angol program hallgatói számára is a nyelv számított az alkalmazkodás szempontjából kiemelkedően a legnehezebbnek csökkenő tendencia mellett. A magyar magatartás- és gondolkodásmódhoz való alkalmazkodás nehézsége növekedést mutatott, a szociális körülmények szempontjához hasonlóan, melyet azonban csak az elsőévesek és a végzős hallgatók jelöltek az öt leggyakoribb tényező között. A másodévesek számára az ország és a lakosok megismerése, míg a felsőbb évesek számára az infrastruk- 
4. táblázat |Az alkalmazkodás szempontjából a legnehezebb - összesített eredmények (minden képzési program)

\begin{tabular}{|c|c|c|c|c|c|c|}
\hline $\begin{array}{l}\text { Dimenziók képzési } \\
\text { programok szerint } \\
\text { (n = jelölések száma) }\end{array}$ & & 1. évfolyam & 2. évfolyam & $\begin{array}{c}\text { Felsóbb } \\
\text { évfolyamok }\end{array}$ & Végzősök & $\begin{array}{l}\stackrel{p}{\text { 1. évfolyam }} \\
\text { - végzősök }\end{array}$ \\
\hline \multirow[t]{2}{*}{ (Magyar) nyelv } & Német nyelvű képzés & $28,0 \%(\mathrm{n}=2410)$ & $28,7 \%(\mathrm{n}=2436)$ & $28,4 \%(\mathrm{n}=1812)$ & $21,8 \%(\mathrm{n}=257)$ & 0,016 \\
\hline & Angol nyelvű képzés & $9,8 \%(\mathrm{n}=1407)$ & $11,9 \%(\mathrm{n}=1584)$ & $9,5 \%(\mathrm{n}=1284)$ & $9,1 \%(n=637)$ & 0,309 \\
\hline \multirow[t]{2}{*}{ Infrastruktúra, bürokrácia } & Német nyelvű képzés & $10,7 \%(\mathrm{n}=2410)$ & $10,4 \%(\mathrm{n}=2436)$ & $11,5 \%(\mathrm{n}=1812)$ & $16,3 \%(\mathrm{n}=257)$ & 0,003 \\
\hline & Angol nyelvű képzés & $-(\mathrm{n}=1407)$ & $-(\mathrm{n}=1584)$ & $10,1 \%(\mathrm{n}=1284)$ & $-(n=637)$ & - \\
\hline \multirow{2}{*}{$\begin{array}{l}\text { Az ország és lakóinak } \\
\text { megismerése }\end{array}$} & Német nyelvű képzés & $9,8 \%(\mathrm{n}=2410)$ & $10,7 \%(\mathrm{n}=2436)$ & $9,5 \%(\mathrm{n}=1812)$ & $-(\mathrm{n}=257)$ & - \\
\hline & Angol nyelvű képzés & $-(\mathrm{n}=1407)$ & $8,4 \%(\mathrm{n}=1584)$ & $-(\mathrm{n}=1284)$ & $-(\mathrm{n}=637)$ & - \\
\hline \multirow[t]{2}{*}{ Szociális körülmények } & Német nyelvű képzés & $8,4 \%(\mathrm{n}=2410)$ & $-(\mathrm{n}=2436)$ & $-(\mathrm{n}=1812)$ & $16,3 \%(\mathrm{n}=257)$ & 0,000 \\
\hline & Angol nyelvű képzés & $6,2 \%-$ & $-(\mathrm{n}=1584)$ & $-(\mathrm{n}=1284)$ & $8,0 \%(\mathrm{n}=637)$ & 0,064 \\
\hline \multirow[t]{2}{*}{ A hazától való távolság } & Német nyelvű képzés & $12,3 \%(\mathrm{n}=2410)$ & $10,5 \%(\mathrm{n}=2436)$ & $9,9 \%(\mathrm{n}=1812)$ & $8,6 \%(n=257)$ & 0,038 \\
\hline & Angol nyelvű képzés & $9,9 \%(\mathrm{n}=1407)$ & $9,2 \%(\mathrm{n}=1584)$ & $8,9 \%(\mathrm{n}=1284)$ & $9,6 \%(\mathrm{n}=637)$ & 0,417 \\
\hline Integráció & Német nyelvű képzés & $-(\mathrm{n}=2410)$ & $9,4 \%(n=2436)$ & $12,4 \%(n=1812)$ & $(\mathrm{n}=257)$ & - \\
\hline $\begin{array}{l}\text { Egyetemi tanulmányok, } \\
\text { egyetemi élet }\end{array}$ & Angol nyelvü képzés & $9,8 \%(\mathrm{n}=1407)$ & $11,9 \%(n=1584)$ & $9,5 \%(\mathrm{n}=1284)$ & $9,1 \%(n=637)$ & 0,309 \\
\hline \multirow{2}{*}{$\begin{array}{l}\text { Magatartás- és gondolko- } \\
\text { dásmód }\end{array}$} & Angol nyelvű képzés & $7,0 \%(\mathrm{n}=1407)$ & $7,6 \%(\mathrm{n}=1584)$ & $10,5 \%(\mathrm{n}=1284)$ & $9,3 \%(\mathrm{n}=637)$ & 0,035 \\
\hline & Magyar nyelvű képzés & $14,0 \%(\mathrm{n}=993)$ & $12,6 \%(\mathrm{n}=1330)$ & $9,5 \%(\mathrm{n}=759)$ & $-(n=441)$ & - \\
\hline Idegen nyelvek használata & Magyar nyelvű képzés & $13,7 \%(\mathrm{n}=993)$ & $10,2 \%(\mathrm{n}=1330)$ & $12,4 \%(\mathrm{n}=759)$ & $10,4 \%(\mathrm{n}=441)$ & 0,044 \\
\hline Anyagi különbségek & Magyar nyelvű képzés & $14,5 \%(\mathrm{n}=993)$ & $19,8 \%(\mathrm{n}=1330)$ & $23,6 \%(n=759)$ & $20,9 \%(n=441)$ & 0,001 \\
\hline Mások megismerése & Magyar nyelvű képzés & $20,0 \%(\mathrm{n}=993)$ & $15,7 \%(\mathrm{n}=1330)$ & $13,8 \%(\mathrm{n}=759)$ & $10,2 \%(\mathrm{n}=441)$ & 0,000 \\
\hline Alkalmazkodás & Magyar nyelvű képzés & $7,5 \%(\mathrm{n}=993)$ & $-(n=1330)$ & $-(n=759)$ & $-(\mathrm{n}=441)$ & - \\
\hline Integráció & Magyar nyelvű képzés & $-(n=993)$ & $9,6 \%(\mathrm{n}=1330)$ & $-(\mathrm{n}=759)$ & $-(\mathrm{n}=441)$ & - \\
\hline Lakhatási különbségek & Magyar nyelvű képzés & $-(\mathrm{n}=993)$ & $-(\mathrm{n}=1330)$ & $8,4 \%(n=759)$ & $10,9 \%(\mathrm{n}=441)$ & - \\
\hline $\begin{array}{l}\text { Különbségek a szórakozási } \\
\text { lehetőségeket tekintve }\end{array}$ & Magyar nyelvű képzés & $-(\mathrm{n}=993)$ & $-(\mathrm{n}=1330)$ & $-(\mathrm{n}=759)$ & $9,8 \%(\mathrm{n}=441)$ & - \\
\hline
\end{tabular}

túra és a bürokrácia is problémát jelent az alkalmazkodásban.

A befogadó közeghez tartozó magyar nyelvü képzés hallgatói csökkenő tendencia mellett az alkalmazkodás szempontjából nehéznek ítélték az ismerkedést, valamint az idegen nyelvek használatát. Növekvő különbséget mutatott a teljes tanulmányi időre vetítve az anyagi lehetőségek különbségeinek szempontja, mint olyan tényező, mely nehezíti az alkalmazkodást. A befogadást és az integrációt - az angol nyelvư képzéshez hasonlóan - csak a másodévesek jelölték, míg a lakhatási és a szórakozási különbségekkel kapcsolatos nehézségeket a felsőbb évesek és a végzősök érzékelték a leginkább.

\section{A fókuszcsoportos vizsgálatok eredményei}

\section{Az eredeti és a befogadó kultúra közötti különbségek}

A fókuszcsoportos interjúk eredményei alapján megállapítható, hogy az idegen nyelvü képzés hallgatói többször említették az életmóddal és életstílussal, illetve a mentalitással kapcsolatos különbségeket, a közlekedési szokások másságát, a hivatalos ügyintézés nehézségeit, vala- mint az eltérő időkezelést - az utóbbi legfóképpen a német hallgatók válaszai kapcsán jelent meg:

„Nem mondanak pontos idôt, hanem azt mondják, majd. Kicsit olyanok, mint a mediterránok." (Német nyelvü képzés hallgatója.)

A felsőbb éves hallgatók kiemelték emellett a szociális és közélettel, a munkához való viszonnyal kapcsolatos különbségeket, valamint a magyar és a külföldi hallgatók közötti, anyagi helyzetből adódó eltéréseket:

„Kár, hogy valószinulleg anyagi okok miatt nem ugyanoda járnak szórakozni, ez neheziti az ismerkedést.” (Angol nyelvü képzés hallgatója.)

\section{Alkalmazkodás egy másik kultúrához - a beilleszkedést lassitó vagy támogató tényezők}

A befogadó kultúrához való alkalmazkodás vonatkozásában a fókuszcsoportokban részt vevő külföldi hallgatók az egyetemi tanulmányokat és az egyetemi életet, a hétköznapi élet helyzeteit (például lakhatás, vásárlás) érezték a leginkább egyszerúnek. A magyar nyelvú képzés hallgatóinak - külföldi társaikhoz hasonlóan - a nemzetközi egyetemi élet és a nemzetközi közegben folytatott 
egyetemi tanulmányok jelentették a legkevesebb problémát.

„Beilleszkedésnél megkönnyitheti a dolgukat, hogy a külföldiek hazánkban talán kicsit különlegesnek számitanak, sokkal inkább, mint egy olyan országban, abol megszokott a sokféle kultúra és nemzet jelenléte. Így gyakrabban érdeklödnek irántuk az emberek, könnyebben kerïlnek kommunikációba, ami a beilleszkedésnél a legfontosabb lehet." (Magyar nyelvü képzés hallgatója.)

$\mathrm{Az}$ alkalmazkodás szempontjából nehezebb tényezőket tekintve az interjúk során a leggyakrabban a nyelvi és kommunikációs problémák kerültek elő a külföldi hallgatók körében. Nehézségként említették még az ügyintézést és a bürokráciát, a befogadó közeg megismerését, valamint a beilleszkedés egyéb tényezőit. Magyar hallgatótársaik az ismerkedést és annak lehetőségeit, emellett az idegen nyelvek használatával kapcsolatos visszafogottságukat tekintve szintén kihívásokról számoltak be. Fontos szempontként merült még fel, hogy anyagi lehetőségeik szempontjából nagy különbségek mutatkoznak, ami a kapcsolódási pontok lehetőségét is leszúkíti.

„Nebéz a magyarok jobb megismerése." (Német nyelvü képzés hallgatója.)

„A hivatali ügyintézés nagyon nehéz.” (Angol nyelvu" képzés hallgatója.)

„A legnebezebb talán a nyelv, és hogy a magyarok sokszor nem túl nyitottak és közvetlenek - ez nyilván személyfüggö, illetve generációfüggö is, de a történelmünk miatt sajnos nemzeti vonásunknak is tekinthetjük." (Magyar nyelvü képzés hallgatója.)

Összességében megállapítható, hogy a fókuszcsoportos interjúk megerősítik a kvantitatív vizsgálat során nyert eredményeket, mind a kultúraközi különbségek, mind pedig a más kultúrákhoz történő alkalmazkodás vonatkozásában.

\section{Megbeszélés}

Az interkulturális kompetencia fejlődésével, valamint a kultúraközi kapcsolódási pontok és együttmúködések kialakulására, illetve fejlődésére vonatkozó hipotézisekkel kapcsolatban vizsgálatunk során az alábbi következtetésekre jutottunk.

A kérdőíves kutatások és a fókuszcsoportos interjúk eredményei alapján egyaránt megerősíthető, hogy mind az idegen nyelvú képzés, mind pedig a befogadó kultúra (elsősorban a magyar hallgatók) interkulturális kompetenciája fejlődik a nemzetközi környezetben. Ez az etnorelatív fázisban $[24,28,30]$ következik be, mely elsősorban a másodévet követően detektálható. A kvalitatív vizsgálatok eredményei megerősítik azt is, hogy az interkulturális készség kialakulását a hallgatók egyértelmúen pozitív kompetenciaként azonosítják, melyet későbbi orvosi munkájukhoz közvetlenül hasznosítható tudásként értékelnek. Mindemellett, a témakörben végzett nemzetközi kutatások is kiemelik, hogy e részkompetenciák fejlesztése és elsajátítása az orvosi tanulmányok mel- lett nem magától értetődő. Elősegítésük, fejlesztésük komplex támogatást igénylő, idő- és energiaigényes feladatot jelent a nemzetközi hallgatókat fogadó egyetemek számára $[4,13]$.

A nemzetközi egyetemi környezet lehetővé teszi az interkulturális kompetencia elsajátítását, annak minden résztvevője számára, hatását tekintve az egyetemen túlmutatóan is. Az e környezetben folytatott tanulmányok alatt, a kultúraközi kapcsolódási pontok és együttmúködések kialakulása és fejlődése által a participáció $[16,17$, 31] és ezáltal a társadalmi tőke erősödése figyelhető meg $[45,46]$. E hipotézisünkkel kapcsolatosan elsősorban a fókuszcsoport-vizsgálatokban jutottunk eredményekhez, melyek azt mutatják, hogy a kultúraközi kapcsolódási pontok a leggyakrabban spontán módon jönnek létre. Az interjúk során azonban arra is fény derült, hogy a szervezett alkalmak megteremtése által, melyek száma az utóbbi években a hallgatói érdekképviseletek szervezésében és/vagy ösztönzésére folyamatosan nő, az együttmúködés lehetősége megteremtődik, a kapcsolódási pontok száma megnő, ezáltal pedig lehetőség nyílik a participáció és a „hídverő” társadalmi tőke megvalósulására és fejlődésére. A problémamegoldásra való törekvés kommunikációs participációs szándéka, azaz az optimálisnak vélt állapot elérésének lehetősége motiváló erőként hathat az interkulturális kompetencia használatára is. Ez a kapcsolathálózatok és ezáltal a bizalom mint társadalmi tőke fejlődését is pozitívan befolyásolhatja, különösen a helyi hallgatói képviseletek integrációt támogató törekvései mellett [41].

Bár a multikulturális közeg a befogadó és a befogadott kultúra részéról egyaránt folyamatos szociokulturális adaptációt igényel, jelenléte által lehetővé válik az interkulturális tudás kognitív, affektív és pragmatikus-kommunikatív részkompetenciáinak részleges vagy adott esetben teljes kialakulása és egyidejű, illetve későbbi alkalmazása, például a minden szempontból egyre inkább multikulturálissá váló egészségügyben.

A nemzetközivé váló munkaerőpiacon az interkulturalitás egyre inkább kulcskompetenciának számít, melynek autentikus elsajátítására a felsőoktatási mobilitás keretében külföldön tanuló, valamint a befogadó kultúra orvosi felsőoktatásában részt vevő hallgatóknak speciális lehetőségük nyílik. A multikulturális közegben elsajátítható kompetenciát az egyetemi képzés keretében további érzékenyítő kurzusokkal lehet célzottan fejleszteni és tudatos szintre emelni $[42,43]$. Emellett érdemes olyan innovatív és elöremutató, hazai és külföldi programokra is figyelemmel lenni, melyek keretében a tanulmányok megkezdésekor az integrációt elősegítő programokkal várják a külföldi orvostanhallgatókat (például a Studienstart International program a Kölni Egyetem szervezésében [14] vagy a berlini Charité ChOIS-programja [15]), valamint olyan tandem- és mentorprogramokat ajánlani [47], amelyek során a magyar és a nemzetközi hallgatók szakmai és interkulturális kompetenciái egyaránt fejlődhetnek [48, 49]. 
Anyagi támogatás: A közlemény megírása, illetve a kapcsolódó kutatómunka anyagi támogatásban nem részesült.

Szerzői munkamegosztás: A kutatás ötletének és szakmai hátterének kidolgozása, a kérdőíves felmérés és az interjúk lebonyolítása, valamint a szövegleiratok elkészítése F. N. munkája. Az eredmények elemzését F. N., P. Zs., B. B. és F. Zs. végezte. A közlemény elkészítésében, szakmai és formai lektorálásában és véglegesítésében F. N., P. Zs., M. E., B. B., F. Zs. és N. T. vett részt. A közlemény végleges változatát valamennyi szerző elolvasta és jóváhagyta.

Érdekeltségek: A szerzőknek nincsenek érdekeltségeik.

\section{Köszönetnyilvánítás}

Köszönjük a PTE ÁOK hallgatóinak segítőkészségét, rendelkezésre állását, nyíltságát és őszinte véleményét.

\section{Irodalom}

[1] Tervalon M, Murray-García J. Cultural humility versus cultural competence: a critical distinction in defining physician training outcomes in multicultural education. J Health Care Poor Underserved 1998; 9: 117-125.

[2] Betancourt JR. Cultural competence and medical education: many names, many perspectives, one goal. Acad Med. 2006; 81: 499-501

[3] Goode TD, Haywood SH, Wells N, et al. Family-centered, culturally, and linguistically competent care: essential components of the medical home. Pediatr Ann. 2009; 38: 505-512.

[4] Huhn D, Junne F, Zipfel S, et al. International medical students - a survey of perceived challenges and established support services at medical faculties. [Internationale Medizinstudierende eine Bestandsaufnahme zu Herausforderungen und Unterstützungsangeboten an den Medizinischen Fakultäten.] GMS Z Med Ausbild. 2015; 32: Doc9. [German]

[5] Marek E, Németh T. Intercultural competence in healthcare. [Interkulturális kompetenciák az egészségügyi ellátásban.] Orv Hetil. 2020; 161: 1322-1330. [Hungarian]

[6] Voigt JJ. Cultural competency - the caregiver connection. Bioethics Forum 2003; 19: 17-23.

[7] Cook CT, Kosoko-Lasaki O, O’Brien R. Satisfaction with and perceived cultural competency of healthcare providers: the minority experience. J Natl Med Assoc. 2005; 97: 1078-1087.

[8] Grützmann T, Rose Ch, Peters T. Intercultural competence in medical practice. [Interkulturelle Kompetenz in der medizinischen Praxis.] Ethik Med. 2012; 24: 323-334. Available from: https://link.springer.com/content/pdf/10.1007\%2Fs00481012-0223-7.pdf [accessed: November 5, 2020]. [German]

[9] Brach C, Fraser I. Can cultural competency reduce racial and ethnic health disparities? A review and conceptual model. Med Care Res Rev. 2000; 57(Suppl 1): 181-217.

[10] van Ryn M, Fu SS. Paved with good intentions: do public health and human service providers contribute to racial/ethnic disparities in health? Am J Public Health 2003; 93: 248-255

[11] Marek E, Kalmár R, Faubl N, et al. Prejudices and their healthcare implications. Lessons learnt from a national survey. [Előítéletek és hatásaik az egészségügyi ellátásban. Egy felmérés tanulságai.] Orv Hetil. 2020; 161: 789-796. [Hungarian]

[12] Dreißig V. Intercultural communication in the hospital. A study of the interaction between hospital staff and migrant patients. [Interkulturelle Kommunikation im Krankenhaus. Eine Studie zur Interaktion zwischen Klinikpersonal und Patienten mit Migrationshintergrund.] Transcript Verlag, Bielefeld, 2005. [German]

[13] Lenz H, Paik WG, Jacobs F. An equal opportunity for everyone?! Supporting international students of medicine at the LudwigMaximilians-University in Munich. GMS J Med Educ. 2018; 35: Doc55.

[14] Karay Y, Restel K, Marek R, et al. Studienstart International of the University of Cologne: the closely supervised semester of study entry for students from third countries using the example of the model degree program for human medicine. GMS J Med Educ. 2018; 35: Doc60.

[15] Marmon W, Arnold U, Maaz A, et al. Welcome, orientation, language training: a project at the Charité for new international medical students. GMS J Med Educ. 2018; 35: Doc59.

[16] Horányi Ö. Communication as a state. Brief overview. (Manuscript.) [A kommunikáció mint állapot. Rövid áttekintés. (Kézirat.)] 2015. Available from: http://www.ozseb.horanyi. hu/kozelet/tanulmanyok/a_kommunikacio_mint_allapot_150607.htm [accessed: January 10, 2017]. [Hungarian]

[17] Horányi Ö. The state of affairs. Synopsis. [A dolgok állása. Szinopszis.] Jel-kép. 2017: 1(1KLSZ): 1-25. Available from: http://communicatio.hu/jelkep/2017/lklsz/JelKep_ 2017_1_kulonszam_Horanyi_Ozseb.pdf [accessed: February 18, 2018]. [Hungarian]

[18] Paasche-Orlow M. The ethics of cultural competence. Acad Med. 2004; 79: 347-350.

[19] Hyun I. Clinical cultural competence and the threat of ethical relativism. Camb Q Health Ethics 2008; 17: 154-163.

[20] Boecker MC, Jäger M. Intercultural competence - key competence of the 21 st century? Theses paper of the Bertelsmann Foundation based on the intercultural competence models by Dr. Darla K. Deardorff. [Interkulturelle Kompetenz - Schlüsselkompetenz des 21 . Jahrhunderts? Thesenpapier der Bertelsmann Stiftung auf Basis der Interkulturellen-Kompetenz-Modelle von Dr. Darla K. Deardorff.] 2006. Available from: http:// www.bertelsmann-stiftung.de/bst/de/media/xcms_bst_ dms_17145_17146_2.pdf [accessed: February 25, 2018]. [German]

[21] Peintinger M. Interculturally competent. A handbook for doctors. [Interkulturell kompetent. Ein Handbuch für Ärztinnen und Ärzte.] Facultas, Wien, 2011. [German]

[22] van Keuk E, Ghaderi C, Joksimovic L, et al. Diversity. Transkulturelle Kompetenz in klinischen und sozialen Arbeitsfeldern. Kohlhammer Verlag, Stuttgart, 2011.

[23] Bhawuk DB. The measurement of intercultural sensitivity using the concepts of individualism and collectivism. Int J Intercult Relat. 1992; 16: 413-436

[24] Bennett MJ. Towards ethnorelativism: a developmental model of intercultural sensitivity. In: Paige M. (ed.) Education for the intercultural experience. Intercultural Press, Yarmouth, ME, 1993; pp. 21-71.

[25] Paige RM, Jacobs-Cassuto M, Yershova YA, et al. Assessing intercultural sensitivity: an empirical analysis of the Intercultural Development Inventory. Int J Intercult Relat. 2003; 27: 467-486.

[26] Engle L, Engle J. Assessing language acquisition and intercultural sensitivity development in relation to study abroad program design. Frontiers: The Interdisciplinary Journal of Study Abroad 2004; 10(1): 219-236.

[27] Greenholz JF. Does intercultural sensitivity cross cultures? Validity issues in porting instruments across languages and cultures. Int J Intercult Relat. 2005; 29: 73-89.

[28] Bennett MJ. Paradigmatic assumptions and a developmental approach to intercultural learning. In: Berg MV, Paige RM, Hemming Lou K. (eds.) Student learning abroad: what our students are learning, what they're not, and what we can do about it. Stylus Publishing, Sterling, VA, 2012; pp. 90-114. 
[29] Deardorff DK, Arasaratnam-Smith LA. (eds.) Intercultural competence in higher education. International approaches, assessment and application. (No. 378 I-6lin). Routledge, London, 2017.

[30] Bennett MJ, Castiglioni I. Embodied ethnocentrism and the feeling of culture: a key to training for intercultural competence. In: Landis D, Bennett J, Bennett M. (eds.) Handbook of intercultural training. Chapter 10. 3rd edn. SAGE Publications, Inc., Thousand Oaks, CA, 2004; pp. 249-265.

[31] Pop M, Hollós S, Mészáros J. Assessment of multiculturalism in nursing based on a survey's experience. $[\mathrm{Az}$ interkulturalitás megítélése az ápolásban egy felmérés tapasztalatai alapján.] Orv Hetil. 2012; 153: 1711-1718. [Hungarian]

[32] Flaskerud J. Cultural competence: what is it? Issues Ment Health Nurs. 2007; 28: 121-123.

[33] Holmes P, Bavieri L, Ganassin S. Developing intercultural understanding for study abroad: students' and teachers' perspectives on pre-departure intercultural learning. Intercult Educ. 2015; 26: $16-30$.

[34] Németh T. The intercultural impact of the Erasmus programme on Hungarian students, with special regard to students of medicine and health care. Doctoral dissertation. [Az ERASMUS program interkulturális hatása magyar hallgatókra, különös tekintettel az orvos- és egészségtudományi hallgatókra. Doktori értekezés.] Pécsi Tudományegyetem, Egészségtudományi Kar, Egészségtudományi Doktori Iskola, Pécs, 2015. [Hungarian]

[35] Harris VW, Kumaran M, Jones Harris H, et al. Assessing multicultural competence (knowledge and awareness) in study abroad experiences. Compare: J Comp Intern Educ. 2019; 49: 430452 .

[36] Németh T, Kajos A. How to develop the intercultural competence of Hungarian students. Porta Lingua 2014; 155-164.

[37] Németh T, Rébék-Nagy G. The importance of intercultural competence within health care. Porta Lingua 2015; 323-333.

[38] Tadaki M. How are we doing higher education internationalisation? University World News, 01 June 2013, issue 274.

[39] Astfalk T, Zhang D, Pérez Anderson RP, et al. On center field or at the sidelines? - A plea for a multimodal approach between medical schools and medical student communities while integrating international medical students. GMS J Med Educ. 2018; 35: Doc61.

[40] Pitts MJ. Identity and the role of expectations, stress, and talk in short-term student sojourner adjustment: an application of the integrative theory of communication and cross-cultural adaptation. Int J Intercult Relat. 2009; 33: 450-462.
[41] Faubl N, Zuhorn F, Füzesi Zs. Possibilities of improving cross cultural and communicative skills in an international environment at the medical school of the University of Pécs. In: Kuráth G, Héráné Tóth A, Sipos N. (eds.) [Kommunikációs és interkulturális kompetenciák fejlődésének lehetőségei a PTE ÁOK nemzetközi környezetében.] In: Kuráth G, Héráné Tóth A, Sipos N. (szerk.) PTE Diplomás Pályakövető Rendszer tanulmánykötet 2014; Pécsi Tudományegyetem, Pécs, 2014; pp. 117-131. [Hungarian]

[42] Faubl N, M. Császár Zs, Wusching ÁT, et al. Foreign medical students studying in Pécs and Debrecen: issues of university choice and integration. [Pécsett és Debrecenben tanuló külföldi orvostanhallgatók: egyetemválasztási és beilleszkedési kérdések.] Metszetek - Társadalomtudományi Folyóirat 2017; 6: 22-43. [Hungarian]

[43] Schulze H, Zhang D, Pérez Anderson RP, et al. Symposium „International medical students - support programs in practical application": Networking, best-practice examples and local representation. GMS J Med Educ. 2018; 35: Doc53.

[44] Hajdu O, Pintér J, Rappai G, et al. Statistics I. [Statisztika I.] Carbocomp Kiadó, Pécs, 1994. [Hungarian]

[45] Fukuyama F. Trust: the social virtues and the creation of prosperity. Free Press, New York, NY, 1995.

[46] Füzér K. The social theory of trust and the sociological theory of social capital. [A bizalom társadalomelmélete és a társadalmi tóke szociológiaelmélete.] Századvég 2015; 78: 5-16. [Hungarian]

[47] Halász R, Rébék-Nagy G. On the teaching of the Hungarian language to medical students. [Az orvostanhallgatói magyar szaknyelv oktatásáról.] Porta Lingua 2019; 175-186. [Hungarian]

[48] Faubl N. Where are future doctors heading? Doctoral ( $\mathrm{PhD})$ dissertation. [Merre tartanak a jövő orvosai?] Pécsi Tudományegyetem, Általános Orvostudományi Kar, Elméleti Orvostudományok Doktori Iskola, Viselkedéstudományok Doktori Program, Pécs, 2018. [Hungarian]

[49] Marek E, Schmél D, Katz Z, et al. Healing and interculturality. [Gyógyítás és interkulturalitás.] Egészségfejlesztés 2019; 60: 6-21. [Hungarian]
(Faubl Nóra dr., Pécs, Szigeti út 12., 7624 e-mail: nora.faubl@aok.pte.hu)

\section{"Ubi sis cum tuis et absis, patriam non desideres." (Ha tiéiddel vagy, hazád nem hiányzik, még ha távol vagy is.)}

A cikk a Creative Commons Attribution 4.0 International License (https://creativecommons.org/licenses/by/4.0/) feltételei szerint publikált Open Access közlemény, melynek szellemében a cikk bármilyen médiumban szabadon felhasználható, megosztható és újraközölhetö, feltéve, hogy az eredeti szerző és a közlés helye, illetve a CC License linkje és az esetlegesen végrehajtott módositások feltüntetésre kerülnek. (SID_1) 